\title{
Diffuse large B cell lymphoma: cutaneous manifestation
}

\author{
Rakesh Sajjan, Athar Haroon, Ziauddin Saad, Irfan Kayani \\ Department of Nuclear Medicine, University College London Hospitals, London, UK \\ Correspondence to Dr Rakesh Sajjan, rakeshsajjan@yahoo.co.uk
}

\section{DESCRIPTION}

A 47-year-old gentleman was diagnosed with diffuse B cell lymphoma. His initial presentation was skin lesions. He was then referred for patch test with a diagnosis of periorbital eczema. Later, patient developed varicose veins and skin lesions in the right leg which was operated upon with poor healing and subsequent skin biopsy of the lesions demonstrated diffuse large B cell lymphoma (DLBCL). The bone marrow biopsy proved marrow involvement. He had no B symptoms. His past medical history includes brain abscess aged 9 months which was operated upon and left him with some weakness on the left side. He is married with two children. No significant illnesses in the family. Patient had six to eight cycles of R-CHOP chemotherapy, however he had progression of lymphoma within

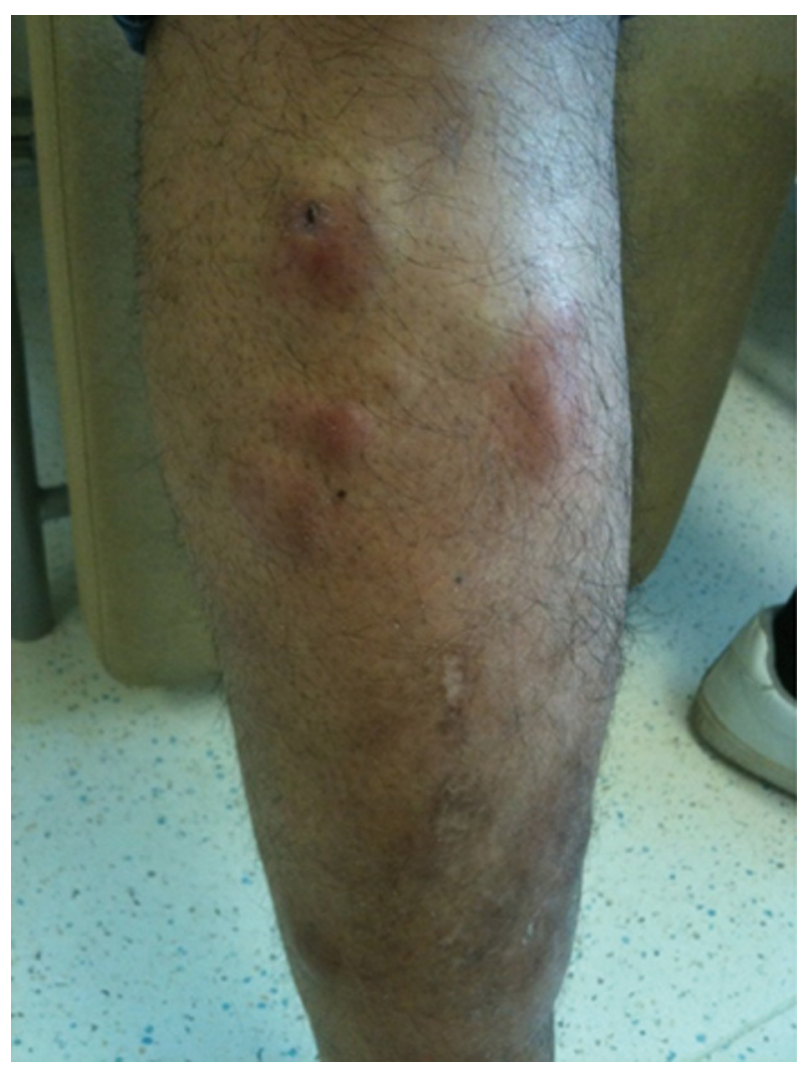

Figure 1 Maculopapular/nodular erythematous skin lesions on the right leg. There is also a surgical scar which is previous venous stripping for varicose veins.
2 months of R-CHOP chemotherapy. He then represented with extensive skin lesions. He was referred for positron emission tomography (PET) scan which was performed using radioisotope 18FDG which confirmed extensive involvement of skin. The pictures show the skin lesions (figure 1) at the time patient was referred for PET and a corresponding picture of PET image (figure 2). The patient had further chemotherapy with oral CCEP (Cytoxan, CCNU, Etoposide and Prednisone) which resulted in complete remission. Currently, he is awaiting peripheral blood stem cell autograft. DLBCL is the most common histological subtype of non-Hodgkin's lymphoma (NHL) accounting for approximately $30-58 \%$ of adult NHL cases. ${ }^{1}$ It is aggressive form of NHL and sixth most common cancer in the UK. ${ }^{2}$ Most frequently, diffuse large cell lymphomas appear in lymphoreticuloendothelial tissues, which include the lymph nodes, spleen, liver and bone marrow. However, any extra nodal site may be primarily or secondarily involved. Skin biopsy from the plaques in such patients showed dense infiltrates of large lymphocytes with irregularly shaped nuclei and prominent nucleoli in the dermis and subcutaneous tissue. ${ }^{3}$ FDG-PET/CT after the first cycles of chemotherapy is useful to monitor treatment due to its high negative predictive value $(87.5 \%)$,

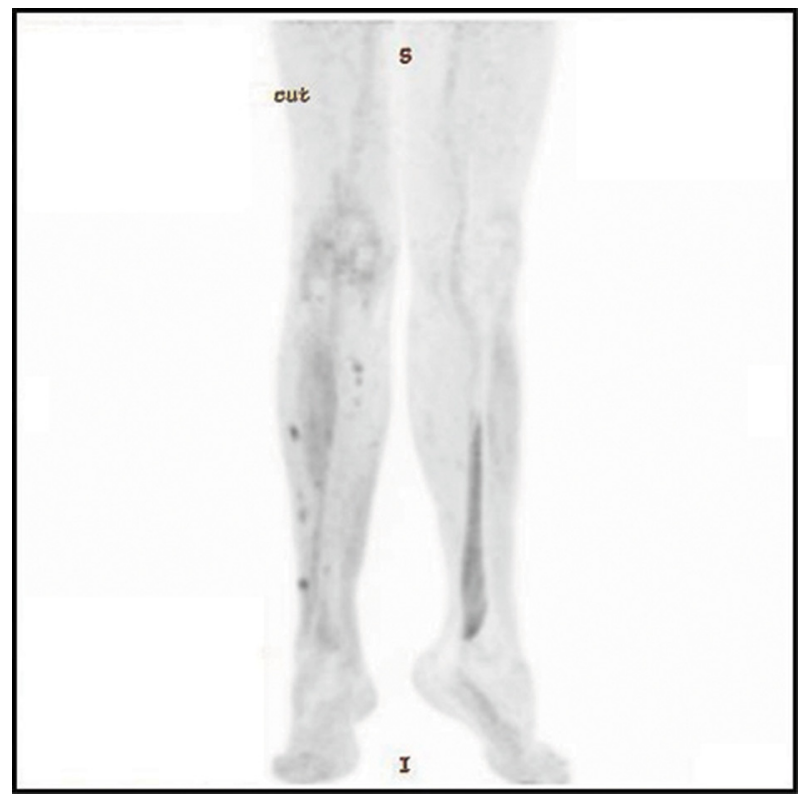

Figure 2 FDG avid lesions in the skin. 


\section{BMJ Case Reports}

using it to modify treatment early in the non-responders. ${ }^{4}$ This case highlights a typical presentation of diffuse B cell lymphoma and PET scan as a modality of investigation. PET scan plays an integral role in the management of such patients and is useful in picking up even extra nodal lesions like skin lesions.

\section{Competing interests None.}

Patient consent Obtained.

\section{REFERENCES}

1. Tilly H, Dreyling M. Diffuse large B-cell non-Hodgkin's lymphoma: ESMO clinical recommendations for diagnosis, treatment and follow-up. Ann Oncol 2009;20:110-12.

2. Kyle F, Hill M. NHL (diffuse large B-cell lymphoma). BMJ Clin Evid 2010;11:2401.

3. Yasuyuki AMO, Tanei R, Yonemoto K, et al. Diffuse large B-cell lymphoma associated with skin, muscle and cranial nerve involvement. Eur J Dermatol 2000;10:306-8.

4. Cortés Romera M, Gámez Cenzano C, Caresia Aróztegui AP, et al. Utility of the PET-CT in the evaluation of early response to treatment in the diffuse large B cell lymphoma. Preliminary results. Rev Esp Med Nucl 2011 (In Press).

This pdf has been created automatically from the final edited text and images.

Copyright 2011 BMJ Publishing Group. All rights reserved. For permission to reuse any of this content visit http://group.bmj.com/group/rights-licensing/permissions.

BMJ Case Report Fellows may re-use this article for personal use and teaching without any further permission.

Please cite this article as follows (you will need to access the article online to obtain the date of publication).

Sajjan R, Haroon A, Saad Z, Kayani I. Diffuse large B cell lymphoma: cutaneous manifestation. BMJ Case Reports 2011;10.1136/bcr.07.2011.4430, Published XXX

Become a Fellow of BMJ Case Reports today and you can:

- Submit as many cases as you like

- Enjoy fast sympathetic peer review and rapid publication of accepted articles

- Access all the published articles

- Re-use any of the published material for personal use and teaching without further permission

For information on Institutional Fellowships contact consortiasales@bmjgroup.com

Visit casereports.bmj.com for more articles like this and to become a Fellow 